\title{
Fundamental Approaches for the Formation of Integrated Corporate Reporting
}

\begin{abstract}
N.A. Prodanova ${ }^{1}$, A.S. Davydova ${ }^{2}$, L.V. Sotnikova ${ }^{3}$, S.S. Shevchenko ${ }^{4}$, N.G. Bochkareva ${ }^{5}$, T.A. Polyanskaya ${ }^{6}$

Abstract:

Purpose: On the basis of the conducted research methodical approaches to formation and disclosure of accounting information for corporate subjects are generalized.

Design/Methodology/Approach: According to its internal content, the process of preparation and presentation of integrated corporate reporting is considered by the authors as a set of procedures that form information about the strategic activities of the organization, the creation of additional value over time and the vision of sustainable business development.

Findings: The study made it possible to establish that the accounting (financial) statements, while retaining their significance in modern conditions, are no longer considered as the only source of information for business. Much of information requests from interested users to go beyond the scope of the financial indicators and ratios disclosed in it, and therefore, various approaches to the formation of so-called non-financial reporting are becoming increasingly important.

Practical implications: The practical significance of the results lies in the development of modern methodological support for the process of preparation and presentation of integrated corporate reporting to create a system of information on various aspects of the performance of the organization, analysis, evaluation, control and justification of strategic management decisions by external and internal subjects of business relations.

Originality: In the course of the study, the authors formulated the concept of creating and preparing integrated corporate reporting, providing maximum disclosure of information on the use of resources (capital) and strategic business opportunities.
\end{abstract}

Keywords: Non-financial reporting, integrated corporate reporting, business model, reporting element, stakeholders.

JEL codes: M21; M40; G32.

Article Type: Research study.

\footnotetext{
${ }^{1}$ Plekhanov Russian University of Economics, Moscow, Russia, prodanova-00@mail.ru

${ }^{2}$ Plekhanov Russian University of Economics, Moscow, Russia.

${ }^{3}$ Financial University under the Government of the Russian Federation, Moscow, Russia.

${ }^{4}$ Russian Presidential Academy of National Economy and Public Administration (RANEPA)

Moscow, Russia.

${ }^{5}$ Plekhanov Russian University of Economics, Moscow, Russia.

${ }^{6}$ Main Control Department of Moscow, Moscow, Russia.
} 


\section{Introduction}

Modern concepts related to the preparation of integrated corporate reporting, as one of the directions for the development of accounting have been received great attention in recent literature. A new approach to the organization and management of accounting and financial business processes with the integration of financial and non-financial information required by a wide range of stakeholders, have recently received increased attention.

A factor in the development of knowledge in the field of information integration, the formation of integrated corporate reporting was Russia's transition from an industrial economy to a digital one, which provides for the formation of an information space taking into account the needs of citizens and society in obtaining high-quality and reliable information. The creation of an economic system whose data in digital form is a key factor in production in all areas of socio-economic activity ensures effective interaction between business, the scientific and educational community, the state and the citizens (Žižka et al., 2018; Saleem et al., 2018; Caplinska and Ohotina, 2019; Tünkler et al., 2016; Chernysheva et al., 2019; Masood et al., 2019).

The adoption, in May 2017, of the Concept for the development of public nonfinancial reporting and the action plan for its implementation, which recognize the high importance of non-financial reporting in modern economic conditions, is a decisive step in increasing the information content of Russian business at the state level. Its essence is that such reporting ensures that various organizations provide "significant, complete, timely, accurate, balanced, comparable, reliable and objective information on their economic, environmental, social and management systems to meet the information needs and requests of stakeholders".

The adoption of the concept allows a new look at the issues of methodological support of integrated reporting. The International Council for Integrated Reporting presents it as "a comprehensive compact message to all interested parties about how the organization's strategy, management, activities and plans for the future, taking into account the external environment, lead to short, medium and long-term creation of additional value". Integrated reporting, the idea of which was initially "based on an attempt to consolidate information - combining into a single system of financial and non-financial performance indicators of the company", is characterized as a modern, actively used channel of information interaction to meet the interests of a wide range of stakeholders.

Today, integrated reporting is seen primarily as an effective way to describe the ability of corporate entities to operate sustainably and maintain the value-creation potential. Its main method is to summarize and integrate key information about management, strategy, risks, operations, financial and non-financial activities. 
According to the developers of the concept of integrated corporate reporting, such a combination of information with the presentation of a wide range of social, managerial, environmental and other issues related to doing business allows us to bring together the accounting and market values of companies due to the wide disclosure of the influence of various factors on the capital of the reporting organization. It is recognized that the increase in the value of the company is largely determined by the ability to manage not only financial and material flows, but also a whole complex of capital and resources: financial, industrial, human, intellectual, natural, social (Korableva et al., 2018; 2019; Goryushkina et al., 2019). At the same time, non-financial indicators subject to disclosure in the traditional reporting are reflected in a truncated manner and are perceived by users of such reporting as insufficiently reliable and incomparable (Prause and Olaniyi, 2019; Lincényi, 2017; Zeibote et al., 2019; Pavolová et al., 2019; Aleksandrova et al., 2017; Dyussembekova et al., 2019; Dunets et al., 2019). Accordingly, they cannot be regarded as a reliable basis for most strategic financial decisions.

In modern conditions, the study of the principles, concepts, constituent elements, methods of compiling annual integrated corporate reports faces many theoretical and practical issues The main ones are: "What should an integrated report contain?"; "What are the main types of resources and capital used by the organization and what they affect?"; "To whom is the organization accountable and what are the information requests of users?"; "What are the business opportunities in the field of measurement, management and connection in a single information space of public and social interaction with the outside world?"; "Is it really possible to cover and report on sustainable development and growth?". The answers to these questions are constantly worrying and bother a huge number of interested managers, executives, consultants, scientists, regulators and owners around the world.

In this regard, the correct understanding of the conceptual content of the processes of integration of accounting and reporting systems, taking into account current trends in the field of doing business and increasing its social responsibility to society, is of importance.

\section{Literature Review}

Despite the development of an international standard for integrated reporting, in Russian practice "the methodology and technology of forming these reports are still in the approbation stage" (Druzhilovskaya, 2015), fundamental work in the field of forming and preparing corporate integrated reporting and a complete objective study of its analytical capacity is not enough (Dalevska et al., 2019). Many well-known domestic scientists are actively involved in this problem, revealing the purpose, nature and content, principles of the requirements for information disclosure. 
Vakhrushina (2014) believes that "an integrated report should disclose the nature of the impact of management on six types of company capital (financial, production, human, intellectual, natural and social)" (Vakhrushina, 2014). At the same time, the information of the integrated report should contain the analysis of the "quality of the organization's relations with its main stakeholders", considering their legitimate interests and expectations (Getman, 2014).

According to I.E. Kalabikhina, D.A. Voloshina, V.S. Dosikova "a new model of integrated reporting is seen as an opportunity to get a more complete picture of the activities of the company in question, which reflects risks and opportunities, while more logically linking the factors of "Environmental, Social and Governance" (ESG, environmental, social and state) and the financial results of the company" (Kalabikhina et al., 2016). To determine the composition of the integrated reporting Kogdenko and Melnik (2014) compare traditional and integrated reporting, revealing the directions of "its transformation into a data system that aggregates key indicators for making management decisions" (Kogdenko and Melnik, 2014). Basing on the concept of "integrated thinking", Malinovskaya (2013) defines, as part of corporate integrated reporting, "the interrelation of financial and management reporting, reports on corporate governance and remuneration, and reports on sustainable development".

A wide discussion has been given to content issues, which are connected with the integration of data of already existing types of accounting, as well as with the mechanism for creating a new type of business accounting, which should become a "motivational element to confirm the correctness of the decisions taken by financial capital providers when allocating resources and reflecting the results of value creation in integrated reporting" (Plotnikov and Plotnikova, 2014). Meanwhile, "the integration process, like any economic process, must be based on the basic rules" (Sorokina, 2008), which indicates the need to improve the methodological support for creating and preparing corporate integrated reporting.

International research and development conducted under the auspices of various international organizations, such as the Association of Certified Chartered Accountants (ACCA), the World Business Council for Sustainable Development (WBCSD), International Federation of Accountants (IFAC), International Integrated Reporting Committee (IIRC), International Institute on Sustainable Development (IISD) and others, play a significant role in this area (Strunc, 2019; Tarman and Dev, 2018; Maguth and Koskey, 2019; Būmane, 2018; Banerjee and Mistri, 2019).

\section{Methodology}

As part of the study, an analysis of domestic experience in the formation of integrated corporate reporting was carried out. As research tools, a systematic analysis of empirical research, the principles of formal logic, synthesis and analysis of theoretical and practical material were used (Boutelier, 2019). 


\section{Results}

According to the authors, one of the key distinctive elements of integrated corporate reporting is information about different types of capital and resources actively involved in the organization's business activities to ensure sustainable development. The multiplicity, and sometimes even the ambiguity of identifying the used capital and resources, dictates the need for full and comprehensive disclosure of information about them, using appropriate methods of accounting and reporting. In our opinion, the modern concept of integrated corporate reporting should be based on information reflecting the full life cycle of the company that form, as a result, information on the strategic activities of the organization, on creating additional value over time and a vision for relatively sustainable business development (Figure 1).

Figure 1. Authors' concept of integrated corporate reporting

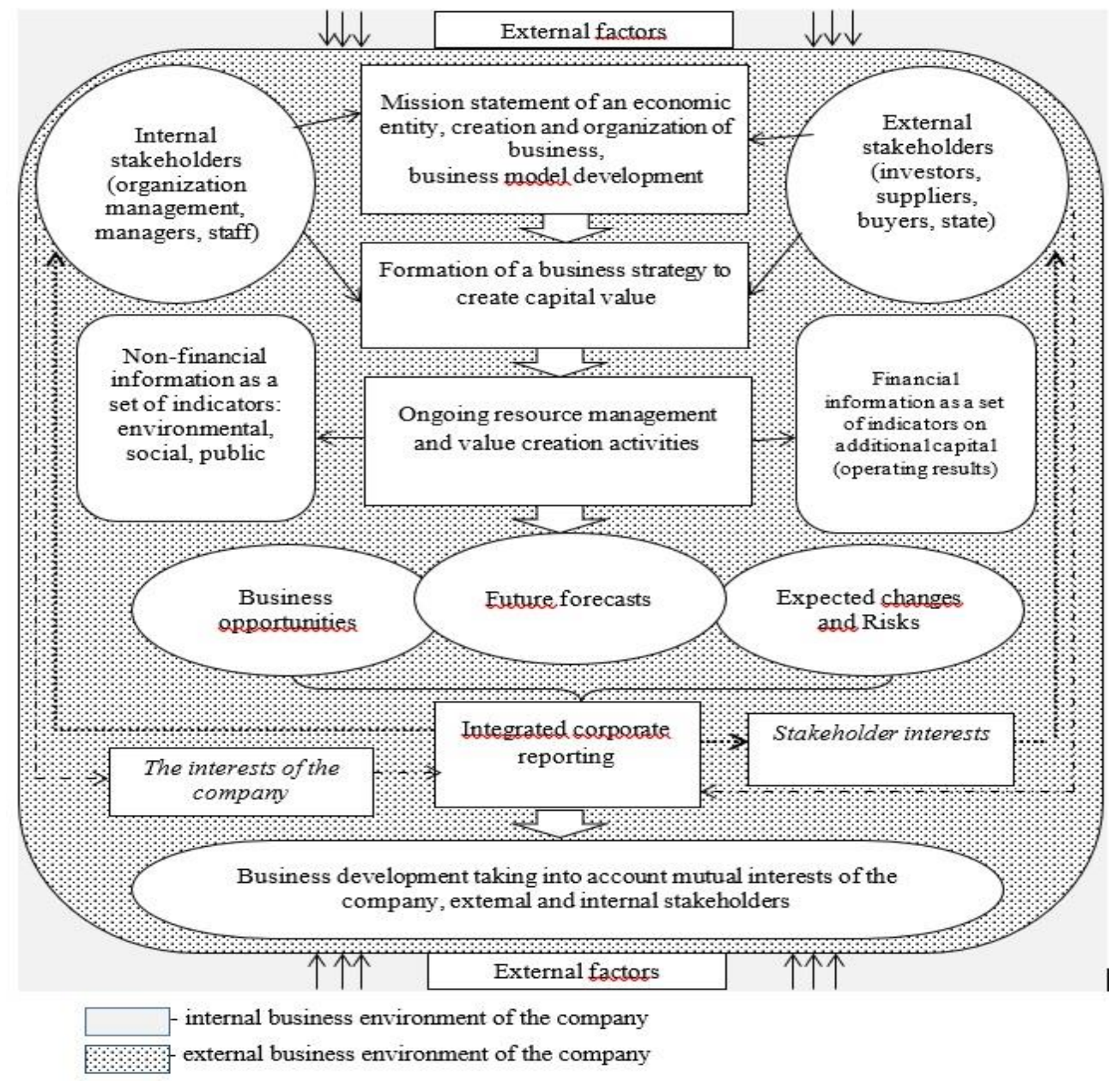


The initial information block of integrated reporting discloses the company's mission in the Russian market, directions of business strategy, individuality of the business model, factors of the internal and external environment that influence the creation of additional value.

Disclosure of the current functioning of the company is the most informative part of the reporting, since the data should characterize the value added received by main activities, and the results of achieving the goal by reflecting financial, public, social and environmental positions, by integrating financial and non-financial indicators (K1lınç et al., 2016; Kaźmierczyk, 2019; Talovina et al., 2017; Leonteva et al., 2018; Koptev et al., 2019; Puryaev, 2015). The stage of a promising future in the integrated report should be disclosed in terms of the forecast for the development of a sustainable business, taking into account the risks and opportunities of the company in the medium and long term.

The implementation of the concept of creation and preparation of integrated corporate reporting provides for improvement of methodological support of the process of information integration, determination of the principles of its generalization and analysis. The main essential characteristic of the integration process is the union of disparate elements into a single whole, which after integration begins to possess additional properties that cannot be reduced to a simple sum of them. Such properties expand information and communication characteristics of the integrated system itself, giving it a new quality - emergence.

It should be noted that a similar approach is used in the modern concept of corporate accounting and reporting, which is based on a single information platform of accounting, management and tax accounting systems, which allows integrating different types of accounting information into a single whole. "The task of integration of accounting types is solved by building and practical implementation of the system of methodological elements of integration applied to all key components and processes of the accounting system" (Malyavko, 2009). "Only information in aggregate and in interconnection allows us to make informed management decisions, which in turn leads to the need to create an integrated accounting system" (Korotkova 2012).

A similar point of view is supported by E.S. Sokolova, Ya.V. Sokolov, A.A. Solonenko, B. Susan, V. Ferdy, D. Foster, E.S. Hendreksen, A.N. Khorin, E.P. Chikunova, L.A. Chikunova, T.V. Shishkova, R. Anthony and others. Such an opportunity to present heterogeneous (financial and non-financial) information in a single format provides the necessary technical basis for its relevant and complete reflection in any corporate reporting formats, including non-financial. The final goal of integrated reporting is to achieve a balance between flexibility and regulation. And the main idea underlying its preparation is to recognize the significant influence of external and internal factors on the stability and financial results of business 
(Smirnova and Soloviov, 2017; Yemelyanov et al., 2018; Smirnova and Rudenko, 2016; Malarev et al., 2018).

Focusing on differences, corporate reporting provides at the same time enough degree of comparability between organizations of different ownership and industry. At the same time, the information disclosed in it also turns out to be heterogeneous, which is noted, in particular, in the provisions of the conceptual framework of international financial reporting standards, which explicitly states that two types of information are subject to disclosure and public presentation: "about the economic resources of the organization and the requirements for the reporting organization. Financial statements also contain information about the consequences of operations and other events that lead to changes in the organization's economic resources and requirements. Both types of information carry useful initial information for making decisions on the provision of organization resources".

Exactly for this reason, the infrastructure for the preparation of any corporate reporting should focus not so much on the rules for measuring and recognizing its articles, disclosing individual issues or evaluating the selected set of key performance indicators, but on a generalized coherent presentation of a variety of information that can provide a comprehensive understanding of the present and future reporting entity (Turen et al., 2019; Monni et al., 2017; Korchevenkov and Aleksandrova, 2017; Alekseenko et al., 2016). For this reason, the infrastructure for the preparation of any corporate reporting should focus not so much on the rules for measuring and recognizing its articles, disclosing individual issues or evaluating the selected set of key performance indicators, but on a generalized coherent presentation of a variety of information that can provide a comprehensive understanding of the present and future reporting entity. In many ways, this is achieved through a separate disclosure and presentation of each of the capital involved in the value chain, which ensures that interested users understand correctly the strategy and potential for increasing added economic value.

The main goal of this approach is to stimulate an active consideration of the interconnections between the various operational and functional units of the organization, the resources used and the types of capital. At the same time, thanks to the integrative thinking promoted by the developers of the concept of corporate integrated reporting, organizations are forced to focus not on individual indicators, but on their cohesive structured in accordance with the needs of the organization, formed taking into account the interdependence of various elements and factors that have a significant impact on business sustainability (Aleksandrova et al., 2015; Gurman et al., 2017; Nikolaeva et al., 2018; Smirnova and Izotov, 2017).

Thus, through the concept of integration there is a logical transition from the concept of corporate reporting to the concept of integrated corporate reporting. It should be noted that at present in the domestic theory and practice of accounting there is no 
complete definition of integrated corporate reporting; therefore, we propose using the following wording: integrated corporate reporting is a coherent presentation in a single document of the most complete reliable information for a wide range of stakeholders on the financial and non-financial performance of the organization in the aggregate revealing the business strategy and prospects for the potential of creating added economic value (Aleksandrova and Talovina, 2017; Yemelyanov et al., 2019). The key elements of integrated corporate reporting, according to the author's definition, are positions that often do not have an accurate and unambiguous valuation. These include:

- environmental factors affecting the company;

- corporate governance features;

- critical success factors;

- long-term strategy;

- opportunities and risks in its implementation;

- business productivity from the point of view of creating all types of capital in the interests of different groups of stakeholders;

- prospects and potential uncertainties for the business model and future activities.

\section{Conclusion}

The practical implementation of the fundamental concepts underlying the formation of integrated corporate reporting involves a reassessment of the internal processes of accounting and corporate reporting. In this regard, there is a natural question, how the traditional accounting sphere will exist (cooperate) with such innovation in corporate reporting. It should be noted that the answer to this question is not obvious. On the one hand, many notions and concepts used in the preparation of integrated corporate reporting relate to notions and concepts used in accounting, such as valuation or equity. On the other hand, in corporate reporting is increasingly introduced such concepts as model, business processes, risks, strategy, etc. Thus, the information content of the information disclosed is significantly increased, but at the same time, the internal requirements for the information collected and presented in accounting registers are also growing.

Obviously, under these conditions, emphasis in the preparation of reports will increasingly be made on the structures and information arrays of management accounting. Accordingly, at the level of the reporting organization naturally there is a need for the formation of a comprehensive information base with the technical ability to integrate and combine in the configurations of its various elements. At the same time, simply using these accounting and managerial accounting registers in these conditions will not be enough and it is obvious that additional processes of communication, collection of initial data, development of new accounting registers should be launched, allowing more fully and accurately present all the necessary financial and non-financial information in formats, most fully satisfying information requests of stakeholders and interests of an economic entity. 


\section{References:}

Aleksandrova, T.N., Tsiplakov, V.N., Romashev, A.O. \& Semenikhin, D.N. 2015. Removal of sorption-active carboniferous components from difficultly treated gold sulfide ores and concentrates of the mayskoye deposit. Obogashchenie Rud, (4), 3-7. http://doi:10.17580/or.2015.04.01

Alekseenko, S.V., Borodulin, V.Y., Gnatus, N.A., Nizovtsev, M.I. \& Smirnova, N.N. 2016. Problems and outlooks for petrothermal power engineering (review).

Thermophysics and Aeromechanics, 23(1). http://doi:10.1134/S0869864316010017

Aleksandrova, T., Aleksandrov, A. \& Nikolaeva, N. 2017. An investigation of the possibility of extraction of metals from heavy oil. Mineral Processing and Extractive Metallurgy Review, 38(2), 92-95. http://doi:10.1080/08827508.2016.1262860

Aleksandrova, T.N. \& Talovina, I.V. 2017. Platinum-group metals in residual soils and potential efficiency of their processing in gravity concentrators. Journal of Mining Science, 53(3), 553-558. http://doi:10.1134/S106273911703250X

Banerjee, R. \& Mistri, B. 2019. Impact of coal mining in diversification of rural livelihoods: A case study in the barjora colliery area of bankura district, west bengal. Space and Culture, India, 6(5), 228-240. http://doi:10.20896/SACI.V6I5.335

Bochkareva, N.G. 2018. Methodical ensuring preparation of the integrated corporate reporting (dissertation). Sciences: 08.00.12, Moscow, Russia, 211.

Boutelier, S. 2019. Limiting Learning Environments through Domestication. Journal of Culture and Values in Education, 2(1), 45-55. http://cultureandvalues.org/index.php/JCV/article/view/29

Būmane, I. 2018. The methodology of the statement of comprehensive income and its impact on profitability: the case of Latvia. Entrepreneurship and Sustainability Issues, 6(1), 77-86. http://doi.org/10.9770/jesi.2018.6.1(6)

Bulyga, R.P. 2015. Approaches to the formation of a complex public reporting of the organization on the basis of the intellectual capital concept. Auditor, 11, 18-29.

Caplinska, A., Ohotina, A. 2019. Analysis of financial literacy tendencies with young people. Entrepreneurship and Sustainability Issues, 6(4), 1736-1749. http://doi.org/10.9770/jesi.2019.6.4(13)

Chernysheva, A.M., Trofimova, A.A., Kalygina, V.V. \& Bulatenko, M.A. 2019. Factors of developing international retail chain brands in the regions of the russian federation. Space and Culture, India, 6(5), 115-123. doi:10.20896/SACI.V6I5.479

Dalevska, N., Khobta, V., Kwilinski, A., Kravchenko, S. 2019. A model for estimating social and economic indicators of sustainable development. Entrepreneurship and Sustainability Issues, 6(4), 1839-1860. http://doi.org/10.9770/jesi.2019.6.4(21)

Druzhilovskaya, T.Yu. 2015. Integrated reporting issues in publications of contemporary scientists. International accounting, 11(353), 55-64.

Dyussembekova, G., Reshina, G., Primbetova, S., Sultanova, M. \& Beisembayeva, G. 2019. Role and importance of the damu enterprise development fund and international investment funds in implementing project and leasing financing programs in Kazakhstan. Space and Culture, India, 6(5), 156-165. doi:10.20896/saci.v6i5.442

Dunets, A., Latysheva, O., Bitter, N., Vakhrushev, I., Shichiyakh, R. \& Zhuruli, G. 2019 The economic and infrastructural basis for the development of tourist space: The essence, structure and typology. Journal of Environmental Management and Tourism, 10(2), 319-327. doi:10.14505/jemt.v10.2(34).05

Get'man, V.G. 2014. The conceptual framework and the structure of international standard 
on integrated reporting. International accounting, 44(338), 2-15.

Goryushkina, N.E., Vakhrushev, I.B., Akhmetova, M.K., Otto, O.V., Pesotskaya, E.V. \& Voinova, N.E. 2018. The world hotel market: Current state and development trends. International Journal of Mechanical Engineering and Technology, 9(12), 618-627.

Gurman, M.A., Aleksandrova, T.N. \& Shcherbak, L.I. 2017. Flotation of low-grade goldand carbon-bearing ore. Gornyi Zhurnal, (2), 70-74. http://doi:10.17580/gzh.2017.02.13

Havlova, K. 2015. What Integrated Reporting Changed: The Case Study of Early Adopters. Paper presented at the Proceedings of the 9th International Scientific Conference on Business Economics and Management (BEM), Tech Univ Zvolen, Izmir, Turkey, 2015. Procedia Economics and Finance, 34, 231-237.

James, M.L. 2015. The benefits of sustainability and integrated reporting: An investigation of accounting majors' perceptions. Journal of Legal, Ethical and Regulatory Issues, 18(1), 1-20.

Kaspina, R.G. 2013. Institutional aspects of high-quality corporate reporting potential. Audit statements, 5,18 .

Kalabikhina I.E., Voloshin D.A., Dosikov V.S. 2015. Integrated reporting as a new level of corporate reporting development. International accounting, 31(373), 47-57.

Kaźmierczyk, J. 2019. Workforce segmentation model: banks' example. Entrepreneurship and Sustainability Issues, 6(4), 1938-1954. http://doi.org/10.9770/jesi.2019.6.4(28)

Korableva, O.N., Kalimullina, O.V., Zaytseva, A.A. \& Larionov, A.I. 2018. Elaboration of database for the subject domain of innovation and economic growth potential. Paper presented at the Proceedings of the 31st International Business Information Management Association Conference, IBIMA 2018: Innovation Management and Education Excellence through Vision 2020, 6065-6073.

Korableva, O.N., Kalimullina, O.V., Mityakova, V.N. 2019. Designing a System for Integration of Macroeconomic and Statistical Data Based on Ontology. Advances in Intelligent Systems and Computing, 998, 157-165.

Kogdenko, V.G. \& Mel'nik, M.V. 2014. Integrated reporting: formation and analysis issues. International accounting, 10(304), 2-15.

Korchevenkov, S.A. \& Aleksandrova, T.N. 2017. Preparation of standard iron concentrates from non-traditional forms of raw material using a pulsed magnetic field. Metallurgist, 61(5-6), 375-381. http://doi:10.1007/s11015-017-0503-z

Koptev, V.Yu., Kopteva, A.V., Poddubniy, D.A. 2019. Increase in Energy Efficiency of Oil and Gas Companies by Perfecting of Management Systems. Proceedings of the 2019 IEEE Conference of Russian Young Researchers in Electrical and Electronic Engineering, ElConRus, 548-552. Doi: 10.1109/EIConRus.2019.8657041.

Kılınç, E., Kılınç, S., Kaya, M.M., Başer, E.H., Türküresin, H.E. \& Kesten, A. 2016. Teachers' attitudes toward the use of technology in social studies teaching. Research in Social Sciences and Technology, 1(1), 59-76.

Leonteva, L.S., Maximov, D.A., Kurbanov, S.A., Afanasyev, I.V., Melnikova, T.E. \& Rezakov, R.G. 2018. Information services and development of effective urban management. International Journal of Civil Engineering and Technology, 9(11), 2518-2525.

Lincényi, M. 2017. Entrepreneurship ecosystem facets: the European migrant crisis and public opinion in Slovakia. Entrepreneurship and Sustainability Issues, 5(2), 357367. http://doi.org/10.9770/jesi.2017.5.2(14)

Maguth, B.M. \& Koskey, K.L.K. 2019. Preparing urban youth to live-up to their civic promise? evaluating youth positionality of civic engagement using an arts-based 
instrument. Journal of Social Studies Education Research, 10(1), 1-37.

Masood, O., Tvaronavičienè, M., Javaria, K. 2019. Impact of oil prices on stock return: evidence from G7 countries. Insights into Regional Development, 1(2), 129137. https://doi.org/10.9770/ird.2019.1.2(4)

Malarev, V.I., Kopteva, A.V., Koptev, V.Yu. 2018. Electric Power Supply System Development for Down-hole Electric Steam Generators to Produce High-viscosity Oil. International Multi-Conference on Industrial Engineering and Modern Technologies, FarEastCon. Doi: 10.1109/FarEastCon.2018.8602954.

Malinovskaya, N.V. 2013. Integrated reporting as an innovative model of corporate reporting. International accounting, 38(214), 12-17.

Monni, S., Palumbo, Tvaronavičienè, M. 2017. Cluster performance: an attempt to evaluate the Lithuanian case, Entrepreneurship and Sustainability Issues, 5(1), 43-57. http://doi.org/10.9770/jesi.2017.5.1(4)

National Standard of the Russian Federation. 2010. Managing for the sustained success of an organization. Approach based on quality management, approved and promulgated by the Order of Rosstandart, (23.11.2010, № 501-senior section 3.2 GOST R ISO 9004-2010).

Nikolaeva, N.V., Aleksandrova, T.N. \& Elbendari, A.M. 2018. Ore strength property evaluation in the design of ore preparation cycles. Paper presented at the Geomechanics and Geodynamics of Rock Masses, 1, 333-338.

Pavolová, H., Bakalár, T., Emhemed, E.M.A, Hajduová, Z., Pafčo, M. 2019. Model of sustainable regional development with implementation of brownfield areas. Entrepreneurship and Sustainability Issues, 6(3), 1088-1100. http://doi.org/10.9770/jesi.2019.6.3(2)

Polenova, S.N. 2012. Institutional model of accounting and reporting regulation in Russia (dissertation). Sciences: 08.00.12, Moscow, Russia, 389.

Prause, G., Olaniyi, E.O. 2019. A compliance cost analysis of the SECA regulation in the Baltic Sea. Entrepreneurship and Sustainability Issues, 6(4), 1907-1921. http://doi.org/10.9770/jesi.2019.6.4(26)

Plotnikov, V.S. \& Plotnikova, O.V. 2014. Concept of preparation financial statements: Concept consolidated financial statements and international concept of integrated reporting. Auditor, 10(234), 42-50.

Prodanova, N.A., Plaskova, N.S., Bochkareva, N.G., Babalykova, I.A., Gazizyanova, Y.Y. \& Zherelina, O.N. 2019a. Integrated Corporate Reporting as An Innovative Business Reporting Model. International Journal of Engineering and Advanced Technology, 8(5), 2075-2078.

Prodanova, N.A., Trofimova, L.B., Adamenko, A.A., Erzinkyan, E.A., Savina, N.V. \& Korshunova, L.N. 2019b. Methodology for assessing control in the formation of financial statements of a consolidated business. International Journal of Recent Technology and Engineering, 8(1), 2696-2702.

Puryaev, A.S. 2015. The mathematical apparatus of compromise of efficiency estimation of investment projects. International Business Management, 9(5), 856-861. https://doi.org/10.3923/ibm.2015.856.861

Saleem, F., Adeel, A., Rizwan, A., Hyder, S. 2018. Intentions to adopt ecopreneurship: moderating role of collectivism and altruism. Entrepreneurship and Sustainability Issues, 6(2), 517-537. http://doi.org/10.9770/jesi.2018.6.2(4)

Sumkova, N.G. 2015. External factors of influence on accounting Institute. Economics and entrepreneurship, 4-1(57-1), 824-831. 
Strunc, A. 2019. The Politics of Culture. Journal of Culture and Values in Education, 2(1), 71-80. http://cultureandvalues.org/index.php/JCV/article/view/26

Sorokina, I.O. 2008. Theoretical foundations of integration concepts and principles of its implementation. Management in Russia and abroad, 2, 2-6.

Smirnova, N.N. \& Izotov, E.A. 2017. Methodology for estimating heat losses due to heat effects on a heterogeneous oil reservoir. Journal of Industrial Pollution Control, 33(1), 950-958.

Smirnova, N.N. \& Soloviov, V.B. 2017. Some aspects of technology improvement of underground coal gasification. Journal of Industrial Pollution Control, 33(1), 873877.

Smirnova, N.V. \& Rudenko, G.V. 2016. Priorities for improving taxation in oil industry in russia. Indian Journal of Science and Technology, 9(19). http://doi:10.17485/ijst/2016/v9i19/93907

Tarman, B. \& Dev, S. 2018. Editorial: Learning Transformation through Innovation and Sustainability in Educational Practices. Research in Social Sciences and Technology, 3(1). http://ressat.org/index.php/ressat/article/view/363

Talovina, I.V., Lieberwirth, H., Alexandrova, T.N. \& Heide, G. 2017. Supergene oxidesilicate nickel deposits: Mineral-geochemical composition and peculiarities of processing. Eurasian Mining, (1), 21-24. http://doi:10.17580/em.2017.01.06

Turen, S., Abdulla, M., Farooq, M.O., Elsoud, M.S.A. 2019. Causes of Non-Performing Loans: The Experience of Gulf Cooperation Council Countries. Entrepreneurship and Sustainability Issues, 6(4), 1955-1974. http://doi.org/10.9770/jesi.2019.6.4(29)

Tünkler, V., Tarman, B. \& Güven, C. 2016. A metaphorical approach regarding the equipment of students with abstract concepts and values included in the citizenship and democracy education curriculum. Egitim Ve Bilim, 41(185), 123-145. http://doi:10.15390/EB.2016.6031

Vakhrushina, M.A. 2014. The accounting paradigm in global economy: Russia's problems and their solutions. International accounting, 25(319), 38-46.

Zeibote, Z., Volkova, T., Todorov, K. 2019. The impact of globalization on regional development and competitiveness: cases of selected regions. Insights into Regional Development, 1(1), 33-47. https://doi.org/10.9770/ird.2019.1.1(3)

Yemelyanov, V., Tochilkina, T., Nedelkin, A. \& Shved, E. 2018. Automation of monitoring and diagnosing the technical condition of torpedo ladle cars. Paper presented at the MATEC Web of Conferences. http://doi:10.1051/matecconf/201823904003

Yemelyanov, V.A., Fatkulin, A.R., Nedelkin, A.A., Titov, V.A. \& Degtyarev, A.V. 2019. Software for weight estimation of the transported liquid iron. Paper presented the Proceedings of the 2019 IEEE Conference of Russian Young Researchers in Electrical and Electronic Engineering, ElConRus, 381-384. http://doi:10.1109/EIConRus.2019.8657011

Žižka, M., Hovorková, H., Valentová, V., Pelloneová, N., Štichhauerová, E. 2018. The effect of clusters on the innovation performance of enterprises: traditional vs new industries. Entrepreneurship and Sustainability Issues, 5(4), 780-794. http://doi.org/10.9770/jesi.2018.5.4(6) 